\title{
Comparative studies on the digestibility of beef, buffalo, camel and mutton fats for chicks
}

\author{
BY M. A. AFIFI* \\ Animal Production Department, Ain Shams University, Cairo, Egypt, UAR
}

(Received I3 Fanuary I97I-Accepted 3 August I971)

\begin{abstract}
I. A comparative study on the digestibility of beef, buffalo, camel and mutton fats was made with chicks during the 4 th week of age. Each fat was added to a low-fat dietat levels of 3,6 and $9 \%$.

2. The mean digestibilities of beef, buffalo, camel and mutton fats were $85.4,72.6,83.9$ and $94.1 \%$ respectively. Thus mutton fat appeared to be significantly superior to other fats, whereas buffalo fat was significantly inferior.

3. The melting points of the fats seemed to have no influence on their digestibilities.

4. With the exception of beef fat, the digestibility of the fats improved as the iodine value increased.
\end{abstract}

During recent years animal fats have been incorporated widely in high-energy rations for broilers. Beef tallow and lard are the principal fats used in some countries, mutton fat being used to a lesser extent.

In Egypt considerable numbers of buffaloes are slaughtered yearly and are an important source of meat for human consumption. Large numbers of camels are also slaughtered in some districts of Egypt and of the countries of the Middle East. At the present time animal fats are not accepted by most consumers, and it is expected that a surplus of these fats will accumulate. An evaluation of such fats is necessary for the development of high-energy rations for poultry.

Although the digestibilities of beef tallow and mutton fat have been determined by several authors, there does not appear to be any information available in the literature concerning the digestibility of buffalo and camel fats.

It was of interest therefore to carry out a comparative study on the digestibility for chicks of beef, buffalo, camel and mutton fats.

\section{EXPERIMENTAL}

\section{Animals and their management}

Unsexed Fayomi chicks, I d old, were used. They were kept in cages with raised wire floors in an electrically heated room to 4 weeks of age. Feed and water were supplied ad lib. The chicks were weighed at weekly intervals and food consumption was recorded.

\section{Diets}

A basal low-fat mash (Table r) was given to the control birds. In the rations in which the animal fats were included, maize starch was replaced on a weight for weight basis with 3,6 and $9 \%$ of either beef, buffalo, camel or mutton fat prepared

\footnotetext{
* Present address: $3^{8} 4$ El-Haram Str., Giza, Egypt, UAR.
} 
as follows. Fatty tissues from camel's hump, sheep's tail, and buffalo's and cow's internal fat were obtained from a number of butcher's shops. They were cut into small pieces, dry-rendered over a low flame in the laboratory, and the extracted fat was recovered.

Table I. Percentage composition of the basal diet

\begin{tabular}{|c|c|}
\hline Maize & 46 \\
\hline Horse bean (Vicia Faba L.) & $r_{3}$ \\
\hline Decorticated cottonseed meal & 12 \\
\hline Maize gluten feed & 10 \\
\hline Maize starch & 9 \\
\hline Dried skim milk & 5 \\
\hline Dried yeast & 2 \\
\hline Bone meal & $2 \cdot 2$ \\
\hline Common salt & 0.4 \\
\hline Mineral mixture* & 0.1 \\
\hline Vitamin mixture† & 0.3 \\
\hline $\begin{array}{l}\text { Crude protein (\%) } \\
\mathrm{ME} / \mathrm{kg} \text { diet (kcal) }\end{array}$ & $\begin{array}{l}18 \cdot 6 \\
2646 \\
\text { II. }\end{array}$ \\
\hline
\end{tabular}

* To give (per kg diet): $0.99 \mathrm{~g} \mathrm{NaCl}, 0.15 \mathrm{~g} \mathrm{MnSO}_{4}, 0.006 \mathrm{FeSO}_{4}, 0.99 \mathrm{mg} \mathrm{KCl}, 0.199 \mathrm{mg} \mathrm{CuO}$, $0.199 \mathrm{mg} \mathrm{MgSO}_{4}, 0.10 \mathrm{mg} \mathrm{ZnO}$, $0.063 \mathrm{mg} \mathrm{CoCl}_{2}$ and $0.021 \mathrm{mg} \mathrm{Kl}$.

$\uparrow$ To give (per $\mathrm{kg}$ diet): 7500 i.u. vitamin A, ${ }_{5} 00$ i.u. cholecalciferol, $6.6 \mathrm{mg}$ riboflavin, $6 \mathrm{mg} \mathrm{D}-$ pantothenic acid, $40 \mathrm{mg}$ nicotinic acid, $\mathrm{I} 7 \mathrm{I} \mathrm{mg}$ choline chloride and $20 \mu \mathrm{g}$ vitamin $\mathrm{B}_{12}$.

\section{Experimental design and analytical methods}

The day-old birds were divided into twenty-six lots of four chicks each. Each experimental ration was given to duplicate lots of birds.

Excreta were collected from each group of chicks for 4 consecutive days starting on the 2ist day of age. The excreta were dried at $80^{\circ}$, mixed, ground and stored in the refrigerator until analysed. Coefficients of digestibility of the fats tested were calculated from dietary fat intake and faecal fat excretion corrected for the fat excreted by the chicks receiving the low-fat diet.

Samples of food and faeces were analysed for ether extract and the melting points of the fats and their iodine values were determined by the methods outlined in the Association of Official Agricultural Chemists (1955).

\section{RESULTS}

\section{Digestibility of the fats}

The results in Table 2 give the mean digestibilities of the tested fats at dietary levels of 3,6 and $9 \%$ and the general mean for the three levels for each fat. The general means were $85.4,72 \cdot 6,83 \cdot 9$ and $94 \cdot 1 \%$ for beef, buffalo, camel and mutton fats respectively. Analysis of variance showed that the differences between the mean digestibilities were highly significant $(P<0.01)$. Mutton fat was significantly superior and buffalo fat significantly inferior in digestibility to all the other tested fats; the digestibilities of beef and camel fats were almost equal. With both camel and mutton fats, raising the dietary level from 3 to $9 \%$ did not show any clear trend in the digestibility coefficients. Beef fat was less well utilized when the fat level was increased 
beyond $6 \%$ of the diet while the digestibility of buffalo fat was depressed when the level was raised beyond $3 \%$.

Table 2 shows that as the iodine value of the fats increased the digestibility was improved. Beef fat was exceptional since its digestibility coefficient $\left(85^{\circ} 4\right)$ was fairly high despite its low iodine value.

The values presented in Table 2 also show that melting point seemed to have no influence on the digestibility of the various fats.

Table 2. Mean digestibility coefficients for chicks, and mean body-weights and food conversion ratio of chicks given different animal fats at dietary levels of 3,6 and $9 \%$

\begin{tabular}{|c|c|c|c|c|c|c|c|c|c|c|}
\hline \multirow[b]{2}{*}{ Fat } & \multirow{2}{*}{$\begin{array}{c}\text { Diet- } \\
\text { ary } \\
\text { level } \\
(\%)\end{array}$} & \multicolumn{2}{|c|}{$\begin{array}{l}\text { Coefficient of } \\
\text { digestibility }(\%)\end{array}$} & \multirow[b]{2}{*}{$\mathrm{SE}$} & \multirow[b]{2}{*}{$\begin{array}{l}\text { Melting } \\
\text { point }\end{array}$} & \multirow[b]{2}{*}{$\begin{array}{l}\text { Iodine } \\
\text { value }\end{array}$} & \multicolumn{2}{|c|}{$\begin{array}{l}\text { Body-weight at } \\
4 \text { weeks }(g)\end{array}$} & \multicolumn{2}{|c|}{$\begin{array}{l}\text { Food conversion } \\
\text { ratio, } 0-4 \text { weeks } \ddagger\end{array}$} \\
\hline & & Mean & $\begin{array}{l}\text { General } \\
\text { mean*** }\end{array}$ & & & & Mean & $\begin{array}{l}\text { General } \\
\text { mean } \dagger\end{array}$ & Mean & $\begin{array}{l}\text { General } \\
\text { mean }\end{array}$ \\
\hline \multicolumn{2}{|c|}{$\begin{array}{l}\text { Control } \\
\text { (no added fat) }\end{array}$} & - & 一 & 一 & - & - & - & $230 \cdot x$ & - & $2 \cdot 43$ \\
\hline \multirow[t]{2}{*}{ Beef } & $\begin{array}{l}3 \\
6\end{array}$ & $\begin{array}{l}86 \cdot 5 \\
88 \cdot 8\end{array}$ & 一 & - & - & - & $\begin{array}{l}253^{\circ} 7 \\
259 \cdot 5\end{array}$ & - & $\begin{array}{l}2 \cdot 44 \\
2 \cdot 27\end{array}$ & - \\
\hline & 9 & 80.9 & $85 \cdot 4$ & $3 \cdot 23$ & 29.8 & $44^{\circ} \circ$ & 211.7 & $241 \cdot 6$ & $2 \cdot 57$ & $2 \cdot 43$ \\
\hline \multirow[t]{2}{*}{ Buffalo } & $\begin{array}{l}3 \\
6\end{array}$ & $\begin{array}{l}81 \cdot 2 \\
64 \cdot 6\end{array}$ & - & - & - & - & $\begin{array}{l}23 I \cdot I \\
24 I \cdot 9\end{array}$ & - & $\begin{array}{l}2 \cdot 45 \\
2 \cdot 62\end{array}$ & - \\
\hline & 9 & $7{ }^{7} \cdot 9$ & $72 \cdot 6$ & $5 \cdot 64$ & 30.4 & $42 \cdot 4$ & $240 \cdot 2$ & $237 \cdot 8$ & $2 \cdot 35$ & $2 \cdot 48$ \\
\hline \multirow[t]{2}{*}{ Camel } & $\begin{array}{l}3 \\
6\end{array}$ & $\begin{array}{l}86 \cdot 1 \\
79^{9} \cdot 2\end{array}$ & - & - & - & - & $\begin{array}{l}236 \cdot 1 \\
238 \cdot I\end{array}$ & - & $\begin{array}{l}2 \cdot 31 \\
2 \cdot 62\end{array}$ & - \\
\hline & 9 & 86.4 & 83.9 & $2 \cdot 3^{6}$ & $33 \cdot 6$ & 65.0 & $223^{\circ} 9$ & $2.32 \cdot 7$ & $2 \cdot 52$ & $2 \cdot 48$ \\
\hline \multirow[t]{2}{*}{ Mutton } & $\begin{array}{l}3 \\
6\end{array}$ & $\begin{array}{l}90 \cdot 0 \\
97 \cdot 7\end{array}$ & - & - & - & - & $\begin{array}{l}24 \mathbf{r} \cdot 9 \\
248 \cdot 7\end{array}$ & - & $\begin{array}{l}2 \cdot 34 \\
2 \cdot 36\end{array}$ & - \\
\hline & 9 & $94 \cdot 5$ & $94^{\cdot I}$ & 3.32 & $28 \cdot 3$ & $7 \mathrm{I}^{\cdot} 5$ & $243^{\circ} \circ$ & $244 \cdot 5$ & 2.24 & $2 \cdot 3 \mathrm{I}$ \\
\hline
\end{tabular}

** Significant $(P<0.01)$ † No value significantly different from control $(P>0.05)$.

$\ddagger$ (g food eaten/g gain).

\section{Body-weights and food conversion ratio}

Table 2 also gives the mean body-weights of the chicks at 4 weeks of age and food conversion ratio ( $\mathrm{g}$ food eaten/g weight gained) during the 4 -week experimental period. The various animal fats failed to improve body-weight gains of the chicks and differences between treatments lacked statistical significance. None of the animal fats seemed to improve feed utilization. The slight improvement observed with the diet containing $9 \%$ mutton fat was not statistically significant.

\section{DISCUSSION}

\section{Digestibility of the fats}

The digestibility for beef fat obtained in this work fell generally within the range reported by other workers. Digestibility values of roo, $8 \mathrm{I}$ and $86 \%$ were obtained by Carver, Rice, Gray \& Mone (1955) in three digestibility trials with chicks, at a dietary fat level of $3 \%$. Petersen \& Vik-Mo ( 1968 ) reported a digestibility coefficient of $9 \mathrm{r} \cdot 3 \%$ for pure beef fat. On the other hand, the digestibility values obtained for beef tallow by Renner \& Hill ( 1960 ) and Young (1961) were lower than those found in the present 
study, being 74 and $71 \%$ respectively. This might be due to differences in quality of the beef fat used in the different experiments.

Duckworth, Naftalin \& Dalgarno (1950) and March \& Biely (1957) reported that the digestibility of fats decreased as their melting points increased. These authors, however, used fats which differed widely in melting point. In the present investigation no relationship was noted between the melting point and the digestibility coefficients of the various fats. Melting points determined in the present studies ranged only from $29 \cdot 6^{\circ}$ to $33^{\circ} 6^{\circ}$. Holmes \& Deuel (I920-I) considered that differences in melting point below a value of $46^{\circ}$ were of little significance for human subjects. Crockett $\&$ Deuel (r947) also reported that the inverse relationship between melting points and digestibility coefficients applied only to fats having melting points greater than $55^{\circ}$.

\section{Body-weight gains and food conversion ratio}

The addition of the various fats to the basal diet did not improve body-weight gains. This result, however, was not unexpected since it agrees with the reports of several authors (Siedler \& Schweigert, r953; Carver et al. 1955; March \& Biely, 1957; Pepper, Slinger \& Sibbald, 1962). March \& Biely (1954) showed that the response of chicks to animal fats varied with the composition of the basal diet. Biely \& March (1954) found that the addition of fat to a $19 \%$ protein diet depressed growth. However, they found that, when fat was added to a diet containing $24-28 \%$ protein, growth was not affected.

It has been reported that the addition of fat to the basal diet improved food conversion ratio (Carver, Rice, Gray \& Mone, 1954; Sunde, I954; Runnels, 1955; Young, I96ז). However, in the present study no significant differences were obtained in food conversion ratio between the various groups of birds.

The author is indebted to Mr M. Amin in the Department of Food Technology, Faculty of Agriculture, Ain Shams University for his valuable technical assistance.

\section{REFEREN CES}

Association of Official Agricultural Chemists. (1955). Methods of Analysis. Washington, DC: Association of Official Agricultural Chemists.

Biely, J. \& March, B. (1954). Poult. Sci. 33, I220.

Carver, D. S., Rice, E. E., Gray, R. E. \& Mone, P. E. (I954). Poult. Sci. 33, 1048.

Carver, D. S., Rice, E. E., Gray, R. E. \& Mone, P. E. (1955). Poult. Sci. 34, 544.

Crockett, M. E. \& Deuel, H. J. Jr (I947). F. Nutr. 33, I87.

Duckworth, J., Naftalin, J. M. \& Dalgarno, A. C. (r950). F. agric. Sci., Camb. 40, 39.

Holmes, A. D. \& Deuel, H. J. (r920-I). Am. F. Physiol. 54, 479 (quoted by Duckworth et al. 1950).

March, B. E. \& Biely, J. (1954). Poult. Sci. 33, 1069.

March, B. E. \& Biely, J. (r957). Poult. Sci. 36, 71.

Pepper, W. F., Slinger, S. J. \& Sibbald, I. R. (1962). Poult. Sci. 4r, I 163.

Petersen, C. B. \& Vik-Mo, L. (1968). Acta agric. scand. 18, 42.

Renner, R. \& Hill, F. W. (1960). Poult. Sci. 39, 849.

Runnels, T. D. (1955). Poult. Sci. 34, 140.

Siedler, A. J. \& Schweigert, B. S. (1953). Poult. Sci. 32, 449.

Sunde, M. L. (1954). Poult. Sci. 33, 1084.

Young, R. J. (r96r). Poult. Sci. 40, 1225. 